\title{
The Effects of the Talent Types on Purchasing Behavior of Beauty-Service products
}

\author{
Koo Insook \\ Professor, Dept., of Consumer Life Information, College of Human Ecology, \\ Chung Nam National University
}

\begin{abstract}
This study aims to examine the effect of talent types on the purchasing behaviour of beauty-service products in 367 adults(female and male). The present study is the first to consider both talent types and the purchasing behaviour of beauty-service products correlates to appearance management behaviour.

Frequency analysis showed that the mean of 8 talent types of 367 participants was 3.324. The highest talent type of 367 participants was interpersonal talent, the lowest talent type was logical-mathematical talent among 8 talent types.

There were statistically significant relationships between the talent types(specially, bodily-kinesthetic talent and interpersonal talent) and the purchasing criteria of beauty-service products on the correlation analysis.

And the effects of 8 talent types on the purchasing frequency of 4 beauty-service products were significant on the regression analysis, specifically, the results showed that the most significant among 8 talent factors was the interpersonal talent, next, the bodily-kinesthetic was. Thus, the more purchasing frequency of beauty-services products, the higher interpersonal talent were, and the better affinity with others were. As a results, the interpersonal talent factor and bodily-kinesthetic talent factor among 8 talent factors were ultimately affecting the appearance management behaviour. The higher the score, it was concluded that the subject was more active in beauty-related behavior.

Conclusively, the appearance is a form of personal asset for one's self-fulfillment, and strong and beautiful appearance is a medium to improve self-esteem and dominance. It is possessing a significant influence in personal satisfaction, self-identity, and social success.
\end{abstract}

Key Words : Talent Types, Purchasing Behavior of Beauty-Service Products, Purchasing Criteria of Beauty-Service Products, Information Resources for Choosing Beauty Parlors.

Corresponding author ; Koo Insook, Tel.+82-42-821-6845

E-mail : iisk@cnu.ac.kr 


\section{Introduction}

The human desire to be beautiful is considered as one of the efforts of humans to deny the origin of human inequality, across the ages and in all countries of the world. Depending on how one manages one's appearance, the type of beauty illustrated rather differs. In some cases, one depicts the beauty of personality and that of memory, in other cases, it is about elegance and the beauty of innocence. Where does the effort of humans to be beautiful stem from? Is it personality? A natural talent? Or is it the environment? The self-being of humans lies in the personality, appearance, and natural talent that each individual possesses. ${ }^{12)}$ The need to analyze which factors have how much of an influence in the effort or the phenomenon of humans to be beautiful can be justified by the massive scale of beauty-related industries. ${ }^{3 / 4)}$ This study focuses on the talent of humans and analyzes the effects of talent types on the purchasing behaviour of beauty- service products.

There are largely three types in managing one's appearance. The first is coloring one's body (body painting) ; second is the covering one's body (body enclosure) ; and the last is disfiguring one's body or forming scars (body modification). The body painting behaviour, except in particular cases, have developed into a cosmetic aesthetic in the form of face makeup, which allows for an active of human emotions.

If we further categorize the area of cosmetic aesthetics into more specific fields, there exists beauty-service industry of face makeup, hair management and styling, skin management, and makeup. Except in special cases, makeup is performed by individuals by themselves and thus it will not be included as the subject of this study. Here, this study will focus on general facial skin care, provided by either in beauty parlors or specialty shops, hair care and hair styling, scalp management, and manicure care services as subjects in order to analyze how the talent factor relates to the number of such services purchased.

This research will try to understand the present condition of everyday lookism in today's society where appearance-related industries founded upon self-esteem to make oneself more beautiful and the experience of social injustice based on looks flourish. ${ }^{5 / 6)}$ Through this, the study continues with the previous research results which concluded that the evidence of lookism is related to personalities, portrayed through number of purchase of general acts of appearance management such as facial skin care, hair styling, manicure care. Moreover, it goes on further to link the purchase records to the talents that is distinguishable between individuals. The result of this study is expected to provide important information to the academia and to the relevant industries.

\section{Theoretical Background}

\section{The Beauty behavior and Self-esteem}

To put it concisely, the appearance management behaviour includes apparel, accessory, cosmetic and grooming, and all behaviour that consists of changing one's body figure or size.

The appearance is a form of personal asset for one's self-fulfillment, and strong and beautiful appearance is a medium to improve self-esteem and dominance. It is possessing a significant influence in personal satisfaction and social success. What is so called as "the 
Koo Insook / The Effects of the Talent Types on Purchasing Behavior of Beauty-Service products

appearance-oriented view", in other words lookism, has been, and currently is, rampant all over the world from and before the 21 st century. Lookism, first mentioned in the published column of William Safire in New York Times Journal in August, 2000, pointed out appearance as a new variable of social discrimination that has gained international recognition, following race, gender, religion, ideology. ${ }^{7)}$

Lookism is defined as the belief that appearance does not only govern the hierarchy between individuals but the success of an individual's life. This is occurring not only in foreign countries but also in Korea; it has given birth to syndromes such as "best-face", "best-body", and to also a social trend where if your appearance does not "live up to it", an individual is at a relative disadvantage, despite all the good education and the ability.

It is not problematic for an individual to manage one's appearance or one's asset. However, if the management becomes extensive and thus becomes appearance-oriented view, then it disturbs an individual's mentality and emotion. Moreover, it becomes one of the origins that makes a society ill. The impact of this phenomenon influences consumption and in general manor of living, as well as the economic outlook. This is due to the fact lookism offers a direction for the individual in selecting which product to prefer and thus there has been active researches on lookism. ${ }^{8 / 9) 10)}$

It is a common fact that such attitudes toward appearance have allowed the diet industries and the cosmetic industries to become massive fields of economy. TV, movies, women's magazines, and mass media have exchanged information regarding the ideal appearance of men and women under the cultural context. The idealization of appearance have become international and used as a yardstick for self-assessment, ultimately affecting the appearance management behaviour. ${ }^{11)-15)}$

The reason for purchase of beauty-service products or managing one's appearance is because in interpersonal relations, the other person's image is mutually constructed through appearance. It is also judged that the appeared image includes skin, hairstyling, makeup, and clothes and eventually portrays a cultural meaning. Image is not something built by itself but transmits symbols related to the individual through continuous meetings and contacts. Therefore, the researcher believes that the purchase of beauty-service products serves as an indicator of the personal and social meaning of appearance in various point-of-views: how do we construct our identity and express it through appearance? How do individuals interact with one another in a community in which they take part? How do people affect and are affected by the culture that they live in? Thus, by providing implications of personal taste and hobby, the result of this study will be able to provide information and contribute to how middle and small sized firms can successfully operate in the beauty-related service area and equally for the beauty-related production industries, where they produce the fundamental products such as cosmetic materials, cosmetics, shampoo, conditioner, and scalp care products, through suggestions of services that can bring out customer satisfaction.

\section{The human talent types}

Talent refers to something that a certain individual is apt in. The fact that there is talent means that there is capacity and furthermore we call those that have exceptional abilities as 
prodigies or geniuses. For a prodigy, three variables - nature, creativity, and character, motivation - are important and we differentiate the field of prodigy into intellectual, artistic, and social areas. Intellectual prodigy includes logical mathematical talent, linguistic talent, spacial talent, and others special talents; artistic prodigy incorporates artistic talent, performance art talent, and other related talents; and lastly, social talent comprehend leadership talent, empathetic and altruistic talent, and other related talents. ${ }^{16)}$ The subjects of this research are not prodigies; the study will be toward ordinary people with more than 4 years of college education, and by understanding the subjects' talent type, it will ultimately analyze the relationship between the talent types and the beauty-service product consumption behavior.

Regarding talent, what one does well does not always correspond to what one wishes to do. This is because what one wishes to do, one performs it if it is something that one is good at, or if it is of use to them, or need it, or have a hobby towards it. The intensity of the desire that one wants to do something is called a passion. The passion(one aspect of the personality) and the capacity(the talent) becomes a driving force for humans to continuously perform or concentrate on a certain process or work. Talent is either innately born with it or is developed by efforts throughout one's life. If an individual has talent, it becomes to easy to execute something and he or she would feel mentally compensated. However, if he or she is forced to do a certain job without capacity or passion, that individual becomes tired easily and would feel vain.

In order to test the categories of talents, this study made use of the survey that was designed to discover the strengths of human character for job choices, initially created by Institute of my dream Job. ${ }^{17)}$ Under the assumption that what a person "wishes to do" and what he or she "does well" may not be identical, the talent measuring tool is designed by focusing on what an individual actually "does well". Talent test survey can be classified into 8 types: spacial talent, logical mathematical talent, physical sporting talent, linguistic talent, musical talent, interpersonal talent, intrapersonal talent, and lastly, nature friendly talent.

Spatial talent is defined as the capacity to accurately perceive visual and spacial world. It correctly senses and understands 30 forms and images and is the ability to change and rotate in his or her head what it has perceived to create something new. Logical mathematical talent refers to the effective use of logical thinking, reasoning power, mathematical thinking and numbers; it is an ability that is related to brilliant mental process such as categorization, reasoning, generalization, hypothesis test, and calculation. The physical sporting talent is the ability communicate ideas, intents, values, and emotions by using one's physical body. It affectively utilizes appropriate amount of physical skills such as sensibility towards stimulus and tactile capacity, physical balance, and hand craft skills. Linguistic talent illustrates the superior ability to reciprocally react with other people by listening to others and using appropriate and diverse vocabularies. This ability sensitively catches out the meaning, sound, rhythm, accent, and intonation of words and makes use of it. Musical talent means the ability to make different tones, lengths, beat, rhythm, and vibration of sound and to analyze it. Furthermore, it requires a deep understanding of music, intuition, the ability to express creativeness. Interpersonal talent is the talent 
that senses and distinguishes other people's feeling, intentions, motivations, and feeling. This is the ability where an individual is able to form harmonious interpersonal relationships with other people. Intrapersonal talent accurately understands about oneself and is the ability to be true to one's emotions. In addition, this talent possesses the ability to take positive actions based upon one's understanding of oneself. Nature friendliness talent shows interest and adaptiveness in the natural environment one lives in : toward animals and plants, mountains, rivers, and fields. These talents also have much knowledge and insight regarding the natural world.

\section{Research methods}

This study resulted in setting up the following research procedure in order to analyze the effects of the talent types on purchasing behavior of beauty-service products.

\section{Research questions}

1) The eight talent factors are derived and differences of groups are analyzed.

2) The correlations between the talent types and buying criteria of beauty service-products, information resources for choosing beauty parlors are analyzed.

3) The correlation between the buying criteria of beauty-service products, information resources for choosing beauty parlors and the purchasing frequency of beauty-service products are analyzed.

4) The effects of the talent types on the buying frequency of beauty -service products are analyzed.

\section{Literature review and survey}

In order to conduct this study, the researchers initially conducted literature research through previous studies and literature available on the subject of psychological and social evidence of modern individual's beauty-related behavior. ${ }^{18) 19)}$ Furthermore, it was followed by a statistical market and beauty-related behavior research on what types of services and products currently exist. Through previous studies and literature, the researchers of this study deducted measurement tools to observe beauty-related behavior and then executed a preliminary research and adapted further and improved these tools for the particulars of this study. The individual subjects of the research was selected by simple sampling and surveys were distributed and collected based on head-to head method.

\section{Measures}

As shown in $\langle$ Table 1$\rangle$, measuring tools were composed with a survey consisting of 72 questions on 5 point likert-type scales $(1=$ strongly disagree to 5 = strongly agree), and a survey consisting of 4 questions on 5 point interval scales, and a survey consisting of 10 questions on nominal scales, including general demographic informations such as age, sex, occupation, job career, major, income, expense for buying clothing, location.

\section{Questionnaire period}

The preliminary survey was carried out over a week targeting male and female adults who are older than 18 to 50's, are located in Seoul city, Daejon City, Sungnam of Gyunggi-do, and Taegu city in South Korea. The survey was conducted from February 25, 2012 to March 30, 
$<$ Table 1> Measures

\begin{tabular}{c|c|c}
\hline \hline classification & number of variables & scale \\
\hline talent types & 72 & 5 point likert scale \\
\hline $\begin{array}{c}\text { the buying frequency } \\
\text { of beauty-service products }\end{array}$ & 4 & interval scale \\
\hline $\begin{array}{c}\text { the buying criteria of beauty-service } \\
\text { products }\end{array}$ & 1 & nominal scale \\
\hline $\begin{array}{c}\text { the information resources for } \\
\text { choosing beauty parlors }\end{array}$ & 1 & nominal scale \\
\hline demographic variables & 8 & \\
\hline total & 86 & \\
\hline \hline
\end{tabular}

2012. The questionnaire survey was carried out on a door-to-door basis. The 387 questionnaires were responded from total 400 questionnaires, and 20 unusable questionnaires were excluded, then 367 were used for the final analysis.

\section{Participants}

Three hundred sixty seven participants took part in this study ; 367 participants were composed with female 172 persons (46.9\%), males 195 persons (53.1\%), and were composed with over 18 to younger than 20 ages(8 persons, 2.2\%), 20s (156 persons, 42.5\%), 30s (76 persons, 20.7\%), 40s( 105 persons, 28.6\%), 50s( 22persons, 6.0\%). Convenience sampling method was used for extraction. Data were collected from adults in city of Seoul, Daejon, Sungnam of Gyunggi-do, and Taegu in South Korea.

\section{Data analysis}

In this paper, PASW version 19.0 was used to run explanatory factor analysis (EFA) to determine the structural characteristics of the questionnaire, was used to examine the reliability for validity among variables, and was calculated to test $X^{2}$ (chi-square) test, ANOVA for the difference of groups. A frequency analysis was performed to compare mean differences on each factors and components related to variables. Correlation, linear regression analysis was operated to predict the effects of independents variables on dependent variables.

\section{Research Results and Discussion}

The results and implications derived from the data of 367 respondents are as follows.

\section{Mean comparison of the 8 talent factors, the difference between groups}

In order to test the categories of talents, this study made use of the survey that was designed to discover the strengths of human character for job choices, initially created by Institute of my dream Job. ${ }^{20)}$ This study applied a talent measuring tool comprised of 72 questions in order to analyze how talent exercises leverage in the purchase of beauty-service products, and if it does have impact, to what extent it does so. This was conducted through survey research and based upon the results of 367 respondents. 
And, in other to determine the structural characteristics of the questionnaire, factor analysis was used. And ANOVA was calculated to test the differences among groups. Reliability Analysis using Cronbach's Alpha was performed on each of the scales of measuring tools. Cronbach's alpha was used to test internal consistency of the measures.

From 72 variables classified, the eight talent factors were extracted by factor analysis, after entering "varimax rotation" and "the number of factor $=1 "$ on computer. As shown in $\langle$ Table 2>, Talent test survey can be classified into 8 types: spacial talent, logical mathematical talent, physical sporting talent, linguistic talent, musical talent, interpersonal talent, intrapersonal talent, and lastly, nature friendly talent. The reliability of 72 variables was Cronbach' alpha $=0.898$, average $=3.324, F=33.983, P<.001$, the minimum value $=2.371$, maximum value $=3.864$ on the reliability analysis and ANOVA.

The reliability, mean, mean order, $F$ values,

$\langle$ Table 2$\rangle$ The total mean and reliability of 72 talent variables

\begin{tabular}{|c|c|c|c|c|c|}
\hline talent factors & $\begin{array}{l}\text { number of } \\
\text { variables }\end{array}$ & $\begin{array}{l}\text { Cronbach' } \\
\text { alpha }\end{array}$ & Mean & $\mathrm{F}$ & $P$ \\
\hline spatial talent & 9 & \multirow{8}{*}{.898} & \multirow{8}{*}{3.324} & \multirow{8}{*}{33.983} & \multirow{8}{*}{$<.001$} \\
\hline logical-mathematical talent & 8 & & & & \\
\hline bodily-kinesthetic talent & 8 & & & & \\
\hline linguistic talent & 10 & & & & \\
\hline musical talent & 9 & & & & \\
\hline interpersonal talent & 10 & & & & \\
\hline intrapersonal talent & 9 & & & & \\
\hline natural talent & 9 & & & & \\
\hline total & 72 & \multicolumn{4}{|c|}{$\begin{array}{l}\text { minimum value }=2.371 \\
\text { maximum value }=3.864\end{array}$} \\
\hline
\end{tabular}

$<$ Table 3> Mean comparison of the 8 talent factors

$N=367$

\begin{tabular}{c|c|c|c|c|c}
\hline \hline talent factors & Mean & $\begin{array}{c}\text { Mean } \\
\text { rank }\end{array}$ & $F$ & $P$ & $\alpha$ \\
\hline spatial talent & 3.311 & 3 & 12.567 & .000 & .807 \\
\hline logical- mathematical talent & 3.195 & $8 \star \star$ & 22.876 & .000 & .845 \\
\hline bodily-kinesthetic talent & 3.253 & 6 & $176.047 \star \star \star$ & .000 & .802 \\
\hline linguistic talent & 3.226 & 7 & 10.275 & .000 & .818 \\
\hline musical talent & 3.256 & 5 & 10.036 & .000 & .820 \\
\hline interpersonal talent & 3.612 & $1 *$ & 53.356 & .000 & .901 \\
\hline intrapersonal talent & 3.389 & 2 & 16.820 & .000 & .773 \\
\hline natural talent & 3.300 & 4 & 11.771 & .000 & .800 \\
\hline \hline
\end{tabular}


significance levels of 8 talent factors derived from 72 variables for measuring talents were as shown in $\langle$ Table 3>. Among the eight talent factors, the highest marked talent was the interpersonal talent $(*)$, the average $=3.612, F=$ 53.356, significance level $P<.001$, Cronbach' alpha $=0.901$, min. $=2.992$, $\max .=3.864$. Among the eight talent factors, the lowest marked talent was the logical-mathematical talent $(* *)$. The mean of logical-mathematical talent was 3.195, $F=22.876, P<.001$, Cronbach' alpha $=0.845$, respectively. Also, ANOVA revealed that the biggest difference among the groups was the bodily-kinesthetic talent $(* \star *), F$ value $=176.047$, significance level <0.001, $\min =2.371, \max =$ 3.847, and Cronbach' alpha $=0.802$ respectively.

\section{Correlations between the 8 talent factors and buying criteria of beauty- service products, information resources for choosing beauty parlors}

1) The buying criteria of beauty-services products

The fundamental value and what is desired by purchasing beauty-related service products differ according to individuals. What one consumes and how he consumes it are related to his personality, individuality and by the environment he is surrounded. However, by using the guidelines such as 1) in choosing something, which does he place more emphasis on, people or object? 2) how specific is his choice?, it is possible to analyze a consumer's motivation(or consumption type) for beauty-service products. The questions, survey design elements, and the frequency to discover the motivations for demand of beauty parlors are listed in <Table 4>.

The motivations for purchase also differs on the consumer type. In order for the beautyservice products to be linked to re-purchase, it would be favorable to analyze various consumers' criteria(guideline) to purchase and to remember which values were the best number(variable or component) in a consumer's choice of purchase and act in response to it.

The highest scored component of purchasing criteria of beauty-services products was "the effectiveness after operating"(21.5\%), "quality of shampoo and rinse service"(20.4\%), "price" $(20.4 \%)$ in order. Also, as shown in $\langle$ Table 4$\rangle$, 121 persons(33.0\%) of 367 respondents were weighted at "the intrinsic elements" in 4 beauty-services products, and 246 persons $(67.0 \%)$ were chosen at "the added value elements" in 4 beauty-services products.

$\langle$ Table 4$\rangle$ The buying criteria of beauty-service products

\begin{tabular}{|c|c|c|c|}
\hline \multicolumn{2}{|c|}{ Components(frequency) } & \multicolumn{2}{|c|}{ Frequency } \\
\hline effectiveness after operating & \multirow{2}{*}{$\begin{array}{c}\text { intrinsic elements } \\
\text { (121persons, } 33.0 \%)\end{array}$} & 78 & $21.3 \%$ \\
\hline quality of materials related to service & & 43 & $11.7 \%$ \\
\hline price & \multirow{6}{*}{$\begin{array}{l}\text { added value elements } \\
\text { (246persons, } 67.0 \% \text { ) }\end{array}$} & 74 & $20.2 \%$ \\
\hline quality of shampoo/rinse service & & 75 & $20.4 \%$ \\
\hline quality of waiting service & & 17 & $4.6 \%$ \\
\hline location of beauty salon & & 26 & $7.1 \%$ \\
\hline facilities and clean, Hygiene & & 36 & $9.8 \%$ \\
\hline feeling of touch in service & & 18 & $4.9 \%$ \\
\hline \multicolumn{2}{|l|}{ total } & 367 & $100.0 \%$ \\
\hline
\end{tabular}


Koo Insook / The Effects of the Talent Types on Purchasing Behavior of Beauty-Service products

$\langle$ Table 5> The information resources for choosing beauty parlors

\begin{tabular}{|c|c|c|c|}
\hline \multicolumn{2}{|c|}{ Components(frequency) } & \multicolumn{2}{|c|}{ Frequency } \\
\hline T. V. & \multirow{6}{*}{$\begin{array}{c}\text { non-personal information } \\
\text { resources } \\
\text { (227persons : } 61.9 \%)\end{array}$} & 27 & $7.4 \%$ \\
\hline fashion magazine & & 38 & $10.4 \%$ \\
\hline radio & & 32 & $8.7 \%$ \\
\hline internet & & 69 & $18.8 \%$ \\
\hline news paper / flyers & & 30 & $8.2 \%$ \\
\hline street promotion & & 31 & $4.9 \%$ \\
\hline family / acquaintance & personal information resources & 140 & $38.1 \%$ \\
\hline \multicolumn{2}{|r|}{ ( } & 367 & $100.0 \%$ \\
\hline
\end{tabular}

2) The information resources for choosing beauty parlors

In choosing a beauty parlor, where the consumers gather their information is not only the consumer's concern but also that of the firms. The detailed factors that influence a consumer's choice in beauty parlor and their respective frequencies are noted in $\langle$ Table 6>. The highest ranked information resources for choosing a beauty parlor was "from friends or relatives". Thus, it illustrates that rather than short-term publicity impact, words-of-mouth of individuals' evaluation of beauty parlors spread to other consumers and therefore, in the point-of-view of the consumers, they are able to gain the most accurate information. In this vein, it becomes evident that the evaluation of family and relatives become an important factor in choosing a beauty parlor. As it can be seen in $\langle$ Table 5>, the consumers tend to gather information from human resources rather than inhuman mediums.

The frequency of non-personal information resources(such as T.V.(7.4\%), internet(18.8\%), fashion magazine(10.4\%), news paper and flyers $(8.2 \%)$ etc.) were 227 persons(61.9\%), the frequency of personal information resources was 140 persons (38.1\%) as shown in <Table 6>. Non-personal information resources contributed with providing trendy hairstyling, a variety of images, and multiple pieces of information to consumers.

3) Correlation between the 8 talent factors and the buying criteria of beauty-service products, information resources for choosing beauty parlors

Correlation analysis between 8 talent factors and purchasing criteria of beauty-services products showed that the bodily-kinesthetic talent and interpersonal talent among the 8 talent factors were significant as shown in $\langle$ Table 6>. There was a significant pearson correlation coefficient $(r(2)=.131, p<.05)$ between the bodily-kinesthetic talent and purchasing criteria of beauty-services products, and there was a significant pearson correlation coefficient $(r(2)=.106, \quad p<.05)$ between the interpersonal talent among the 8 talent factors and purchasing criteria of beauty-services products.

But there was not a significant pearson correlation coefficient between 8 talent factors and information resources for choosing beauty parlors. 
$\langle$ Table 6$\rangle$ Correlations between the 8 talent factors and the purchasing criteria of beauty-service products, information resources for choosing beauty parlors

\begin{tabular}{c|c|c}
\hline \hline Pearson Coefficient & $\begin{array}{c}\text { The purchasing criteria of } \\
\text { beauty-service products }\end{array}$ & $\begin{array}{c}\text { The information resources } \\
\text { for choosing beauty parlors }\end{array}$ \\
\hline spatial talent & .005 & .017 \\
\hline logical mathematical talent & .037 & .005 \\
\hline bodily kinesthetic talent & $.131 *$ & -.043 \\
\hline linguistic talent & .049 & -.011 \\
\hline musical talent & .045 & -.012 \\
\hline interpersonal talent & $.106 *$ & -.088 \\
\hline intrapersonal talent & .051 & -.008 \\
\hline natural talent & .021 & -.053 \\
\hline \hline
\end{tabular}

3. Correlation between the purchasing criteria of beauty-service products, information resources for choosing beauty parlors and the purchasing frequency of beauty-service products

In this chapter, first, the component comparisons of "the purchasing frequency of beauty-service products" such as skin-care, hairstyling-care, scalp-Care, and manicure-care were performed on the crossing-tab analysis, and second, the relationships between "the purchasing criteria of beauty-service products", "information resources for choosing beauty parlors" and "the purchasing frequency of beauty-service products" were operated on the correlation analysis. The results and implications are as follows.

1) The Crossing tab of skin-care, hairstylingcare, scalp-Care, and manicure-care

The 4 variables intended to research in to the behavior to beautify oneself or giving changes in hair were constructed of the interval scales As shown in $\langle$ Table 7$\rangle$, the interval scales were divided into "not cared by the professionals", "sometimes cared for", "more than once a month", "more than once two weeks", and "more than once a week" and they were given a score of 1 , $2,3,4,5$, respectively. The higher the score, it was concluded that the subject was more active in beauty-related behavior.

The frequency, mean, standard deviation, $x^{2}$ showing the differences among the groups, and significance level of 4 variables were as shown in $\langle$ Table 7$\rangle$. The total reliability of 4 variables was Cronbach' alpha $=0.703, \quad F=341.901$, $\mathrm{P}<0.001, \operatorname{mini}=1.926, \max =3.638$.

Crossing tab analysis showed that the chi-square of the purchasing frequency of skin-care was 163.309, the chi-square of purchasing frequency of hairstyling was 113.397 , the chi-square of purchasing frequency of scalp-care was 138.836, and the chi-square of purchasing frequency of manicure-care was 168.344. And crossing tab analysis showed that the significance levels of 4 variables were $p<.001$. Thus, the higher the chi-square were, it was concluded that the variables were more different among groups

The frequency analysis showed that the 188 persons (51.2\%) of 367 respondents served skin-care were responded with "more than once time per two weeks". 
Koo Insook / The Effects of the Talent Types on Purchasing Behavior of Beauty-Service products

$\langle$ Table 7$\rangle$ The Crossing tab of purchasing frequency of beauty-service products

\begin{tabular}{|c|c|c|c|c|c|}
\hline \multicolumn{2}{|c|}{ Variables and Components } & \multicolumn{2}{|c|}{ Frequency } & Mean & SD \\
\hline \multirow{5}{*}{$\begin{array}{l}\text { frequency of } \\
\text { skin-care }\end{array}$} & not cared by professionals & 17 & $4.6 \%$ & \multirow{6}{*}{3.4305} & \multirow{6}{*}{.90230} \\
\hline & sometimes cared for & 34 & $9.3 \%$ & & \\
\hline & more than once a month & 109 & $29.7 \%$ & & \\
\hline & more than once two weeks & 188 & $51.2 \%$ & & \\
\hline & more than once a week & 19 & $5.2 \%$ & & \\
\hline total & $X^{2}=163.309, P<.001$ & 367 & $100 \%$ & & \\
\hline \multirow{5}{*}{$\begin{array}{l}\text { frequency of } \\
\text { hairstyling }\end{array}$} & not cared by professionals & 20 & $5.4 \%$ & \multirow{6}{*}{3.6376} & \multirow{6}{*}{.90657} \\
\hline & sometimes cared for & 23 & $6.3 \%$ & & \\
\hline & more than once a month & 52 & $14.2 \%$ & & \\
\hline & more than once two weeks & 247 & $67.3 \%$ & & \\
\hline & more than once a week & 25 & $6.8 \%$ & & \\
\hline total & $X^{2}=113.397, P<.001$ & 367 & $100 \%$ & & \\
\hline \multirow{5}{*}{$\begin{array}{l}\text { frequency of } \\
\text { scalp-Care }\end{array}$} & not cared by professionals & 36 & $9.8 \%$ & \multirow{6}{*}{2.8937} & \multirow{6}{*}{1.0413} \\
\hline & sometimes cared for & 92 & $25.1 \%$ & & \\
\hline & more than once a month & 134 & $36.5 \%$ & & \\
\hline & more than once two weeks & 85 & $23.4 \%$ & & \\
\hline & more than once a week & 20 & $5.4 \%$ & & \\
\hline total & $X^{2}=138.836, \quad P<.001$ & 367 & $100 \%$ & & \\
\hline \multirow{5}{*}{$\begin{array}{l}\text { frequency of } \\
\text { manicure } \\
\text {-care }\end{array}$} & not cared by professionals & 175 & $47.7 \%$ & \multirow{6}{*}{1.9264} & \multirow{6}{*}{1.1272} \\
\hline & sometimes cared for & 106 & $28.9 \%$ & & \\
\hline & more than once a month & 34 & $9.3 \%$ & & \\
\hline & more than once two weeks & 42 & $11.4 \%$ & & \\
\hline & more than once a week & 10 & $2.7 \%$ & & \\
\hline total & $X^{2}=168.344, P<.001$ & 367 & $100 \%$ & & \\
\hline
\end{tabular}

Hair is not a necessary factor in everyday life but it improves the quality of life and it is a part of the body that portrays human forms to seem more human. The portrayal of hair condition and style has developed in diverse styles over the ages. If we look into the history of Eastern and Western hair styles, there were periods where men had also long hair and it was only after the 1910 that a short-cut hair for women came into fashion. The history of diverse hairstyling goes far back proves that hair serves as a method of expressing humanness. The root of hair, which is the condition of the scalp, has a close relationship with the growth of hair.

By results, 247 persons(67.3\%) were responded with "more than once a week" in the question about purchasing frequency of hairstyling-care. Thus, results revealed that respondents, for appearance management, were weighed to hairstyling-care more than skin-care.

Also, results reported that 134 persons( 36.5 $\%$ ) were responded with "more thant once a week" in the question about purchasing frequency of scalp- care. 85 persons (23.4\%) were responded with "more than once per two weeks", professionals say it was really effective that scalp-care should be served with "more than once per two weeks".

The word manicure comes from the combination of latin for hand, "manus" and 
"cura", which means care, protection, treatment, and decoration. Manicure is defined as the entire process of arrangement of nail shape, organizing cuticles, managing the dead skin, hand massage and masks, and coloring. Today, manicure is more performed in manicure specialist shop than in beauty parlors and due to the development of artificial nails, beautiful nail arts are knowing a huge success. The number of people who does not go to manicure specialists for nail care was 175 people(47.7\%) and the average number was 1.9264. The reason that the number of manicure care was the lowest out of 4 questions was because, out of total number of respondents, 195 were male respondents and it was found that most of men do not purchase manicure care.

2) Correlation between the purchasing criteria of beauty-service products, information resources for choosing beauty parlors and the purchasing frequency of beautyservice products

Correlation analysis showed there were statistically significant relationship between "information resources for choosing beauty parlors", "purchasing criteria of beauty- service products" and "purchasing frequency of beautyservice products". As shown in <Table 8>, correlation analysis showed there were negative significant between "information resources for choosing beauty parlors" and "purchasing frequency of hairstyling-care", "purchasing frequency of scalp-care" among 4 the purchasing criteria of beauty-service products. The results showed that the more information resources for choosing beauty parlors were, the less purchasing frequency of hairstyling-care(e $(r(2)=-.119)$ and purchasing frequency of scalp-care were $(r(2)=-.162)$.

On the other hand, correlation analysis showed there were positive significant $(p<$. 001)between buying criteria of beauty-services products and purchasing frequency of skincare $(r(2)=.228)$, purchasing frequency of hairstyling-care $(r(2)=.206)$, purchasing frequency of scalp-care(r(2)=.229).

This results that there were not statistically significant between "information resources for choosing beauty parlors", "buying criteria of beauty-service products" and "purchasing frequency of manicure-care" issued from the reasons that the male respondents were bigger than female respondents, and not served with manicure-care.

<Table 8> Correlations between the information resources for choosing beauty parlors, the purchasing criteria of beauty-services products and the purchasing frequency of beauty service products

\begin{tabular}{c|c|c}
\hline \hline Pearson Coefficients & $\begin{array}{c}\text { The information resources for } \\
\text { choosing beauty parlors }\end{array}$ & $\begin{array}{c}\text { The buying criteria of beauty } \\
\text {-services products }\end{array}$ \\
\hline $\begin{array}{c}\text { purchasing frequency } \\
\text { of skin-care }\end{array}$ & -.005 & $.228 * *$ \\
\hline $\begin{array}{c}\text { purchasing frequency } \\
\text { of hairstyling-care }\end{array}$ & $-.119 *$ & $.206 * *$ \\
\hline $\begin{array}{c}\text { purchasing frequency } \\
\text { of scalp- care }\end{array}$ & $-.162 * *$ & $.229 * *$ \\
\hline $\begin{array}{c}\text { purchasing frequency } \\
\text { of manicure-care }\end{array}$ & .015 & .049 \\
\hline \hline
\end{tabular}

$\mathrm{N}=367, \quad *=\mathrm{p}<.05, \quad * \star=\mathrm{p}<.001$ 


\section{The effects of the talent factors on the purchasing frequency of beauty- service products}

In this chapter, for examining the effects of 8 talent factors on the purchasing behaviour of beauty-service products such as skin-care, hairstyling-care, scalp care, and manicure care, that allows an individual to be more beautiful, linear regression analysis was operated. The independents variables were the 8 talent factors, the dependent variables were the purchasing frequency of skin-care, hairstyling-care, scalp-care, and manicure- care. The results and implications are as follows.

1) The effects of the talent factors on the purchasing frequency of skin-care

Skin-care has its purpose in maintaining healthy and beautiful skin, and as a condition for healthy skin there needs to be appropriate amount of moisture, soft elasticity, and certain amount of glossiness. Furthermore, it is advisable to rely on the knowledge of skin medicine in order to achieve the ideal skin. In order to discover the effect that the talent type has on the number of skin management, the researchers selected the number of skin care as dependent variable and executed a linear regression analysis.

As shown in $\langle$ Table 9>, regression showed that the effects of bodily-kinesthetic talent and interpersonal talent factors among the 8 talent factors on the dependent variable(the purchasing frequency of skin-care) were statistically significant. Also, regression reported that if the interpersonal talent factor of participants increases by one standard deviation, the purchasing frequency of skin-care increases by .604(standardized efficient $B=0.604$ ), if the bodily kinesthetic talent increases by one standard deviation, the purchasing frequency of skin-care decreases by .136(standardized efficient $B=-.136)$, and reported that explanatory power( prediction power ) was $30.3 \%\left(R^{2}=0.303, \quad F=19.470, \quad P<0.001\right)$. Thus, it revealed that the interpersonal talent and bodily-kinesthetic talent were predictors of dependent variable (the purchasing frequency of skin-care).

2) The effects of the talent factors on the purchasing frequency of hairstyling

In the era where the image of appearance takes up a large proportion in evaluating other people, there is a growing interest in hairstyling, which can complement the figure of a face or make a certain image more apparent. Hairstyling's advantage lies in the fact that it can be changed easily compared to other appearance managing methods. Depending on a hairstyling, an individual's image can change

$\langle$ Table 9> The effect of the talent factors on the purchasing frequency of skin-care

\begin{tabular}{c|c|c|c|c}
\hline \hline \multirow{2}{*}{8 talent factors } & \multicolumn{3}{|c}{ The purchasing frequency of skin-care } \\
\cline { 2 - 5 } & $\mathrm{B}$ & $\begin{array}{c}\text { standardized } \\
\text { efficient B }\end{array}$ & $\mathrm{t}$ & $\mathrm{P}$ \\
\hline constants & 3.431 & & 86.294 & $<.001$ \\
\hline bodily-kinesthetic talent & -.122 & -.136 & -2.387 & $=017$ \\
\hline interpersonal talent & .545 & .604 & 10.773 & $<.001$ \\
\hline \hline
\end{tabular}

$R^{2}=.303, \quad F=19.470, P<.001, \mathrm{~N}=367$ 
and in the search of a better quality of life, hairstyling occupies an absolute position.

For determining the effects of the talent types on the purchasing frequency of hairstyling-care, linear regression analysis was operated. regression model was entering method, the independent variables were 8 talent factors, the dependent variable were the purchasing frequency of hairstyling-care.

As shown in $\langle$ Table 10$\rangle$, regression showed that the effect of the interpersonal talent among the 8 talent factors on the dependent variable (the purchasing frequency of hairstyling-care) was statistically significant. Also, regression reported that if the interpersonal talent of participants increases by one standard deviation, the purchasing frequency of hairstyling-care increases by .608(standardized efficient $B=$ 0.608). And regression reported that explanatory power(prediction power) was $40.4 \%\left(R^{2}=0.404\right.$, $F=30.357, P<.001)$.

3) The effects of the talent factors on the purchasing frequency of scalp-care
Modern day people undergo permanent, bleach, coloring, coating, drying, hair conditioning and more in order to express their individuality. However, these treatments are the causes of dead skin cells on the scalp, dry hair conditions, and dandruff. In addition, these conditions combined with stress, pollution, and genes results in accelerating hair loss phenomenon and thus the necessity and the seriousness of scalp care, especially to workers, are seeing light. In particular, under the circumstances where there is an increase in the fear of becoming bald among young men, more and more men are receiving scalp care.

For defining the effects of the talent factors on purchasing frequency of scalp- care, linear regression analysis was operated. regression model was entering method, the independent variables were 8 talent factors, the dependent variable were the purchasing frequency of scalp-care.

As shown in $\langle$ Table 11>, regression showed that the effects of the interpersonal talent, natural talent among the 8 talent factors on the

$\langle$ Table 10> The effects of the talent factors on the purchasing frequency of hairstyling-care

\begin{tabular}{c|c|c|c|c}
\hline \hline \multirow{2}{*}{8 talent factors } & \multicolumn{3}{|c}{ The purchasing frequency of hairstyling-care } \\
\cline { 2 - 5 } & $\mathrm{B}$ & $\begin{array}{c}\text { standardized } \\
\text { efficient } \mathrm{B}\end{array}$ & $\mathrm{t}$ & $\mathrm{P}$ \\
\hline constants & 3.638 & & 94.491 & $<.001$ \\
\hline interpersonal talent & .551 & .608 & 11.715 & $<.001$ \\
\hline \hline
\end{tabular}

$<$ Table 11> The effect of the talent factors on the purchasing frequency of scalp-care

\begin{tabular}{c|c|c|c|c}
\hline \hline \multirow{2}{*}{8 talent factors } & \multicolumn{3}{|c}{ The purchasing frequency of scalp- care } \\
\cline { 2 - 5 } & $\mathrm{B}$ & $\begin{array}{c}\text { standardized } \\
\text { efficient } \mathrm{B}\end{array}$ & $\mathrm{t}$ & $\mathrm{P}$ \\
\hline constants & 2.894 & & 58.684 & $<.001$ \\
\hline interpersonal talent & .415 & .399 & 6.546 & $<.001$ \\
\hline natural talent & .128 & .123 & 2.204 & $=.028$ \\
\hline
\end{tabular}

$R^{2}=.195 . \quad F=10.840, P<.001, \quad \mathrm{~N}=367$ 
Koo Insook / The Effects of the Talent Types on Purchasing Behavior of Beauty-Service products

dependent variable(the purchasing frequency of scalp-care) were statistically significant. And, regression reported that if the interpersonal talent of participants increases by one standard deviation, the purchasing frequency of scalpcare increases by .399(standard efficient $B=$ 0.399), and regression reported that if natural talent of participants increase by one standard deviation, the purchasing frequency of scalpcare increases by .123(standardized efficient $B=0.123)$. Also, regression reported that explanatory power(prediction power)was 19.5\% $\left(R^{2}=.195 . F=10.808, P<.001\right)$.

Thus, regression revealed that interpersonal talent and natural talent among the 8 talent factors were predictors of the purchasing frequency of scalp-care.

4) The effects of the talent factors on the purchasing frequency of manicure-care

Today, if one receives an artificial nail treatment which can be stuck on just as if it is a person's own nail. Therefore many women are consuming manicure treatment as it can bring about a higher self-esteem of oneself and can effectively appeal one's image. Due to this, the number of manicure specialist jobs are increasing and they are seeing great success.

For examining the effects of the talent factors on the purchasing frequency of manicure-care, linear regression analysis was operated. Regression model was entering method, the independent variables were 8 talent factors, the dependent variable were the purchasing frequency of manicure-care.

As shown in $\langle$ Table 12$\rangle$, regression showed that the effects of the bodily-kinesthetic talent, interpersonal talent among the 8 talent factors on the purchasing frequency of manicurecare(the dependent variable)were statistically significant. Also, regression reported that if the bodily-kinesthetic talent of participants increases by one standard deviation, the purchasing frequency of manicure-care increases by .304(standard efficient $B=.304$ ), and that if the interpersonal talent of participants increase by one standard deviation, the purchasing frequency of manicure-care increases by .135 (standard efficient $B=.135$ ). Also, regression reported that explanatory power(prediction power) was $16.4 \%\left(R^{2}=.164\right.$. $\left.F=8.767, P<.001\right)$.

Thus, regression revealed that the bodilykinesthetic talent and interpersonal talent among the 8 talent factors were predictors of purchasing frequency of manicure-care.

As mentioned in the above, the bodilykinesthetic talent factor and interpersonal talent factor among 8 talent factors were ultimately affecting the acts of appearance management.

$\langle$ Table 12> The effects of the talent types on the purchasing frequency of manicure-care

\begin{tabular}{c|c|c|c|c}
\hline \hline \multirow{2}{*}{8 talent factors } & \multicolumn{4}{|c}{ The purchasing frequency of manicure-care } \\
\cline { 2 - 5 } & $\mathrm{B}$ & $\begin{array}{c}\text { standardized } \\
\text { efficient } \mathrm{B}\end{array}$ & $\mathrm{t}$ & $\mathrm{P}$ \\
\hline constants & 1.926 & & 35.412 & $<.001$ \\
\hline bodily- kinesthetic talent & .343 & .304 & 4.953 & $<.001$ \\
\hline interpersonal talent & .152 & .135 & 2.203 & $=.028$ \\
\hline \hline
\end{tabular}

$R^{2}=.164 . \quad F=8.767, P<.001, \mathrm{~N}=367$ 
The higher the score, it was concluded that the subject was more active in beauty-related behavior.

\section{Conclusion}

The effects of talent factors on the buying behaviour of beauty-service products from data composed with female 172 persons (46.9\%), males 195 persons (53.1\%) collected through questionnaire, were operated on the correlation, linear regression analysis.

Results showed that the effects of the independents variables on the dependent variable were statistically significant. Specially, they revealed that the interpersonal talent and bodily kinesthetic talent among 8 talent factors were predictors of the dependent variables, the more detail conclusions are as follows :

Frequency analysis showed that the talent factor of 367 participants was mean=3.324. By factor analysis, from 72 variables for measuring talents were derived 8 talent factors named spatial talent, logical mathematical talent, bodily kinesthetic talent, linguistic talent, musical talent, interpersonal talent, intrapersonal talent, and natural talent.

Correlation analysis showed that there were statistically significant relationships between the bodily-kinesthetic and interpersonal talent factors and the buying behaviour of beauty-service products, information resource for choosing beauty parlors.

Frequency analysis showed that the most component of the buying criteria of beautyservice products was "the effectiveness after operating", and the most component of the information resource for choosing beauty parlors was "the recommendation of family and close acquaintance". Thus, the results suggest that both the buying products evaluation and personal satisfaction with the beauty parlers were affected by consumers more than advertising.

The motivations for purchase also differs on the consumer type. When purchasing something, if an actual consumer prefers honest, diligent and frugality, he or she will select price as the most important factor in purchasing; if a consumer is the Inquiring Type, believing that something is worth exploring, he will be interested in the quality of the related materials and the changing trend. Artistic Type of a consumer, who considers innovation and individualism as core values, will likely place importance on style(or form) as motivation for beauty-service product purchase. For the Social Type, where kindness and friendliness towards other people are important, they will emphasize on factors such as the closeness with the hairdresser, attitude of the service provider. And the adventurous and extroverted Entrepreneur Type will show interest in the service quality while waiting and the equipment available. The Traditional Type, who places his value in the tradition and shows administrative characteristics, will display interest in the hygiene and cleanness, and in the location of the beauty parlor. In order for the beauty-service products to be linked to re-purchase, it would be favorable to analyze various consumers' guideline to purchase and to remember which values were the number one variable in a consumer's choice of purchase and act in response to it.

Correlation analysis showed that there were statistically significant relationships between the buying frequency of 3 beauty-service products, except manicure-care and the purchasing criteria 
Koo Insook / The Effects of the Talent Types on Purchasing Behavior of Beauty-Service products

of beauty-service products, information resources for choosing beauty parlors.

Also, Regression analysis revealed that the effects of 8 talent factors on the buying frequency of 4 beauty-service products were significant, specifically, regression results showed that the most significant among 8 talent factors was interpersonal talent, bodilykinesthetic talent in order. Interpersonal talent was positive, social skills, outgoing, and friendly talent, as it were, managing appearance as well as inner-person. Thus, the more buying frequency of beauty services products, the higher interpersonal talent were, and the better affinity with others were. As mentioned in the above, the bodily-kinesthetic talent factor and interpersonal talent factor among 8 talent factors were ultimately affecting the acts of appearance management. The higher the score, it was concluded that the subject was more active in beauty-related behavior.

In interpersonal relationships, a mutual image is constructed through each other's appearance and the word "image" includes skin, hairstyling, manicure, makeup, accessory, and clothes. Image, which contains a cultural context, does not form by itself. It is created between contacts and meetings. An individual's appearance transmits certain symbols about oneself. Therefore, looking into how we form our identity through our appearance, how we interact with others in the community, and how we give and take influences to and from the culture becomes relevant in various ways to consider an appearance's personal. and social context, which in turn, relates to the purchase of beautyservice products.

Conclusively, the appearance is a form of personal asset for one's self-fulfillment, and strong and beautiful appearance is a medium to improve self-esteem and dominance. It is possessing a significant influence in personal satisfaction, self-identity, and social success.

The impact of this phenomenon influences consumption and in general manor of living, as well as the economic outlook. This is due to the fact lookism offers a direction for the individual in selecting which product to prefer and thus there has been active researches on lookism.

\section{Reference}

1) Kaiser, S. B.(1997). The social psychology of clothing : Symbolic appearances in context (2nd ed., rev.). New York : Fairchild Publications, pp.181-208.

2) Tricia Widner Johnson and Sally K. Francis, Lesile Davis Burns (2007), "Appearance Management Behavior and the Five Factor Model of Personality ", Clothing and Textiles Research Journal, 25(3), pp.230-243.

3) Jaeha Lee and Kim K. P. Johnson(2009), "Factors Related to Engagement in Risky Appearance Management Behavior", Clothing and Textiles Research Journal, 27(3), pp. 163-178.

4) Nancy A. Rudd, Sharron J. Lennon(2001), "Body Image : Linking Aesthetics and Social Psychology of Appearance", Clothing and Textiles Research Journal, 19(3), pp.120-133.

5) J. Kevin Thompson, Lesile J. Heinberg (1999), "The Media' s Influence on Body Image Disturbance and Eating Disorders: We' ve Reviled Them, Now Can We Rehabilitate Them? ", Journal of Social Issues, 55(2), pp.339-353.

6) Hayley Dohnt \& Marika Tiggemant(2006). "The contribution of peer and media 
influences to the development of body satisfaction and self-esteem in young girls: A prospective study", Developmental Psychology, 42(5), pp.929-936.

7) William Safire(2000), New York Times, August.

8) Kim K. P. Johnson, Nancy A. Schofield, Jennifer Yurchisin(2002), "Appearance and Dress as a Source of Information: A Qualitative Approach to Data Collection", Clothing and Textiles Research Journal, 20(3), pp.125-137.

9) Jennifer L. Muth and Thomas F. Cash(1997), "Body-Image Attitudes :

What Difference Does Gender Make?", Journal of Applied Social Psychology, 27(16), pp.1438-1452.

10) Jaechee Jung, Sharron J. Lennon, Nancy A. Rudd(2001), "Self-Schema or SelfDiscrepancy? Which Best Explains Body Image?", Clothing and Textiles Research Journal, 19(4), pp.171-184.

11) Nancy A. Rudd, Sharron J. Lennon(2001), "Body Image : Linking Aesthetics and Social Psychology of Appearance", Clothing and Textiles Research Journal, 19(3), pp.120-133.

12) Tricia Widner Johnson and Sally K. Francis, Lesile Davis Burns (2007), op.cit.

13) Jaeha Lee and Kim K. P.Johnson(2009), op. cit.
14) J. Kevin Thompson, Lesile J. Heinberg (1999), "The Media' s Influence on Body Image Disturbance and Eating Disorders: We' ve Reviled Them, Now Can We Rehabilitate Them? ", Journal of Social Issues, 55(2), pp.339-353

15) Hayley Dohnt \& Marika Tiggemant(2006). "The contribution of peer and media influences to the development of body satisfaction and self-esteem in young girls: A prospective study", Developmental Psychology, 42(5), pp.929-936.

16) Cho, Hyunjoo(2004), "Difference of perception about student's scientific talents and interest among students themselves, their parents, and their teachers", Master' D. thesis of Pusan National University.

17) Institute of my dream job(2012), http:// cnu.mydreamjob.co.kr

18) Labat K. L. \& Delong M.(1998). "Body Cathexis and Satisfaction with fit of apparel", Clothing and Textiles Research Journal, 8(2), pp.3-44.

19) Ann Marie Fiore (2010), Understanding Aesthetics for the Merchandising and Design Professional, Fairchild Publications : New York, pp.101-117.

20) Institute of my dream job(2012), op.cit.

Received Jun. 18, 2012

Revised (Jul. 2, 2012)

Accepted Jul. 5, 2012 